\title{
Effect of Nutrient Management Practices on Yield Attributes, Yield, Nutrient uptake and Economics of Pigeonpea (Cajanus cajan L.) Cultivars during Rabi Season
}

\author{
Sunil Kumar Samantaray*, Manoranjansatapathy and Satyananda Jena \\ Department of Agronomy, College of Agriculture, Odisha University of Agriculture and \\ Technology Bhubaneswar-751003, Odisha, India \\ *Corresponding author
}

\section{A B S T R A C T}

K e y w o r d s
Nutrient
management,STBF
R, Total nutrient
uptake, Economics

A field experiment was conducted to study the effect of different nutrient management practices for pigeonpea (Cajanus cajan L.) cultivars at Agronomy Main Research Station, OUAT, Bhubaneswar during rabi 2018-2019. The experiment was laid out in Factorial randomized block design with twelve treatment combinations being replicated thrice. Four nutrient management practices viz. $\mathrm{F}_{1}-\mathrm{STBFR}, \mathrm{F}_{2}-75 \% \mathrm{STBFR}+\mathrm{FYM}\left(5 \mathrm{t} \mathrm{ha}^{-1}\right), \mathrm{F}_{3}-\mathrm{F}_{2}+$ lime $(0.2 \mathrm{LR}), \mathrm{F}_{4}-\mathrm{F}_{3}+$ sulphur $\left(20 \mathrm{~kg} \mathrm{~h}^{-1}\right)$ were applied to three different pigeonpea cultivars (BRG-4, BRG-5 and Laxmi (ICPL-85063). The nutrient management practice of $75 \%$ STBFR+ FYM $\left(5 \mathrm{t} \mathrm{ha}^{-1}\right)+$ lime $(0.2 \mathrm{LR})+$ sulphur $\left(20 \mathrm{~kg} \mathrm{ha}^{-1}\right)$ recorded maximum number of pods plant ${ }^{-1}(44.58)$, total number of seeds $\operatorname{pod}^{-1}(3.84)$, seed index $(12.65 \mathrm{~g})$, seed yield $\left(2061.33 \mathrm{~kg} \mathrm{ha}^{-1}\right)$ and stalk yield $\left(5763.33 \mathrm{~kg} \mathrm{ha}^{-1}\right)$ and Among the cultivars, Laxmi recorded maximum number of pods plant ${ }^{-1}$ (43.90), total number of seeds pod ${ }^{-1}$ (4.03) and seed index $(12.11 \mathrm{~g})$ resulting maximum seed yield $\left(2111.17 \mathrm{~kg} \mathrm{ha}^{-1}\right)$, stalk yield (5639.67 $\left.\mathrm{kg} \mathrm{ha}^{-1}\right)$ and highest harvest index (27.23\%). Higher values of total nutrient uptake viz. nitrogen $\left(177.03 \mathrm{~kg} \mathrm{ha}^{-1}\right)$, phosphorus $\left(13.82 \mathrm{~kg} \mathrm{ha}^{-1}\right)$, potassium $\left(57.47 \mathrm{~kg} \mathrm{ha}^{-1}\right)$ and sulphur $\left(4.53 \mathrm{~kg} \mathrm{ha}^{-1}\right)$ were estimated in cultivar Laxmi and application of $75 \%$ STBFR+ FYM $\left(5 \mathrm{t} \mathrm{ha}^{-1}\right)+$ lime $(0.2 \mathrm{LR})+$ sulphur $\left(20 \mathrm{~kg} \mathrm{ha}^{-1}\right)$ recorded the highest total $\mathrm{N}$ uptake of $183.38 \mathrm{~kg} \mathrm{ha}^{-1}$, total $\mathrm{P}$ uptake of $16.16 \mathrm{~kg} \mathrm{ha}^{-1}$, total $\mathrm{K}$ uptake $58.22 \mathrm{~kg} \mathrm{ha}^{-1}$ and total S uptake of $4.79 \mathrm{~kg} \mathrm{ha}^{-1}$ resulting a total NPKS uptake of $262.55 \mathrm{~kg} \mathrm{ha}^{-1}$. The highest net return $\left(73,856 \mathrm{Rs}^{-1} \mathrm{~h}^{-1}\right)$ and B:C ratio (2.55) were recorded at nutrient level of $75 \%$ STBFR+ FYM (5t ha-1) + lime $(0.2 \mathrm{LR})+\operatorname{sulphur}\left(20 \mathrm{~kg} \mathrm{ha}^{-1}\right)$. Maximum net return (Rs.80,680 Rs.ha ${ }^{-1}$ ) and benefit cost ratio (2.84) was recorded in cultivar Laxmi, which was significantly higher than other cultivars .

\section{Introduction}

Pulses occupy a significant place in India especially for vegetarian people and are considered as rich source of protein. Pulses are rich in amino acid lysine which can supplement the deficiency of this amino acid in cereal dietaries and being at par with milk's protein in the terms of biological efficiency. Due to this reason pulses have also been 
called the "Poor man's meat". Besides the rich sources of protein and vitamins, the legumes play an important role in conserving natural resources (soil, water and micro-flora) by providing excellent soil cover, adding huge amount of organic matter through profuse root system, leaf fall and biomass and improving soil physical conditions (soil aggregates, infiltration rate and water holding capacity). An estimate shows that 139-175 million tonnes nitrogen is biologically synthesized by legumes (Burns and Hardy, 1975). Pulses maintain soil fertility, through biological nitrogen fixation in soil and thrive well under harsh climate of dry land areas (Kanniyan, 1999). With the introduction of improved varieties and promotion of better management techniques, pulse crops can continue to be an excellent choice for farmers in the developing world. As a steady source of nutrition, feed for animals, and soil sustainability, pulse crops play a major role in food security.

Pigeonpea is commonly known as Tur or Arhar (Red gram) in India and is the second important pulse in the country after gram. Seed contains $22.3 \%$ protein, $1.7 \%$ fat and considerable amount of vitamins and minerals. Pigeonpea (Cajanus cajan L.) is a kharif, or rainy-season, crop sown in JuneJuly, with the onset of the monsoon in various agro-climatic zones of India. It is grown as a sole crop on marginal, sub-marginal, and river bed lands with good drainage. Now-a-days introduction of pigeonpea under rabi situation is gaining momentum to make the demand for pulse requirement. Reddy et al., (2015) recommended two varieties of pigeonpea (TRG-22 and LRG-41) were suitable for rabi season and second fortnight of September was the optimum time of sowing for post rainy season. Panda et al., (2018) reported that the pigeonpeavariety Manak performed best among all varieties tested during pre-rabi season in Odisha condition.
There is a need for judicious management of plant nutrients through application of different fertilizers to increase the productivity and to reduce the production costs of pigeonpea. Keeping these objectives in view, the present experiment was designed to find out the effect of nutrient management practices on yield attributes, yield, nutrient uptake and economics of pigeonpea cultivars during rabi season.

\section{Materials and Methods}

The field experiment was conducted in the Agronomy Main Research Station of College of Agriculture, Odisha University of Agriculture and Technology, Bhubaneswar during rabi 2018-19 The experimental site is located at $20^{\circ} 15^{\prime} \mathrm{N}$ Latitude and $85^{\circ} 52^{\prime} \mathrm{E}$ Longitude at an elevation of $25.9 \mathrm{~m}$ above the mean sea level. The station falls under the East and South Eastern Coastal Plain Agroclimatic Zone of Odisha. The soil of the experimental site is sandy loam in texture, acidic in reaction (pH-5.4),electrical conductivity of $0.15 \mathrm{dS} \mathrm{m}^{-1}$ medium in organic carbon, $(0.52 \%)$, low in nitrogen $\left(215.34 \mathrm{~kg} \mathrm{ha}{ }^{-1}\right)$, high in available phosphorus(42.32 $\mathrm{kg} \mathrm{ha}^{-1}$ ), low in available potassium(120.12 $\left.\mathrm{kg} \mathrm{ha}^{-1}\right)$ and low in available sulphur (6.2 ppm). The experiment was laid out in Factorial randomized block design with twelve treatment combinations being replicated thrice. Four nutrient management practices viz. $\mathrm{F}_{1}-\mathrm{STBFR}, \mathrm{F}_{2}-$ $75 \%$ STBFR+FYM $\left(5 \mathrm{t} \mathrm{ha}^{-1}\right), \mathrm{F}_{3}-\mathrm{F}_{2}+$ lime (0.2 LR), $\mathrm{F}_{4}-\mathrm{F}_{3}+$ sulphur $\left(20 \mathrm{~kg} \mathrm{ha}^{-1}\right)$ were applied to three different pigeonpea cultivars BRG-4, BRG-5 and Laxmi (ICPL 85063). After the land preparation FYM and lime were applied in the field as per the treatment. The crop was sown on $12^{\text {th }}$ November 2018 with a spacing of $30 \mathrm{~cm} \times 10 \mathrm{~cm}$. Required quantity of nitrogen, phosphorus and potassium were applied in the form of urea $(46 \% \mathrm{~N})$, diammonium phosphate (18-46- 
$0)$ and muriate of potash $\left(60 \% \mathrm{~K}_{2} \mathrm{O}\right)$ at the time of sowing of the crop. All other cultural practices were followed as per the recommendation. The crop was raised under irrigated condition with adequate plant protection measures. The crop was harvested on $20^{\text {th }}$ March 2019. The gross return, net return and $\mathrm{BC}$ ratio was calculated based on market price of crop. The data collected from the experiment was subjected to statistical analysis by following 'Analysis of variance' technique. The critical difference (CD) values at $5 \%$ level of probability were computed for making comparison between the treatments (Gomez and Gomez, 1984).

\section{Results and Discussion}

\section{Yield attributes}

Yield of a crop is the manifestation of its yield attributing characters. Nutrient management practices shows significant effect on yield attributes of pigeonpea cultivars viz. number of pods plant ${ }^{-1}$, number of seeds $\operatorname{pod}^{-1}$, pod length and 100-seed weight. This might be due to availability of different nutrient during the crop growth and development. The interaction effect of nutrient management practices and cultivar on yield attribute viz. number of seeds pod $^{-1}$ was found to be non-significant.

Among the cultivars, Laxmi was observed with the highest number of pods plant ${ }^{-1}$ (43.90), higher number of seeds $\operatorname{pod}^{-1}(4.03)$, maximum pod length (5.14) and the highest 100 -seed weight $(12.11 \mathrm{~g})$. This variation in yield attributing characters among the cultivars might be due tothe variation in yield potential as influenced by genetic composition. This corroborated with findings of Umesh et al., (2015). Application of 75\% STBFR + FYM $\left(5 \mathrm{t} \mathrm{ha}^{-1}\right)+$ lime $(0.2 \mathrm{LR})+$ sulphur $\left(20 \mathrm{~kg} \mathrm{ha}^{-1}\right)$ resulted in maximum number of pods plant ${ }^{-1}(44.58)$, higher number of seeds $\operatorname{pod}^{-1}$ (3.84), pod length (5.10) and the highest 100 -seed weight $(12.65 \mathrm{~g})$. This might be due to impact of different nutrient management practices to meet the nutrient demand of the crop at the critical stages.

\section{Yield}

Seed yield is a function of interaction of various yield components such as number of pods plant ${ }^{-1}$, number of seeds pod $^{-1}$ and seed weight. It is also a result of cumulative effect of several growth factors mainly comprising of genetic, environmental and management aspects corresponding to meet the optimum need of the crop at different growth stages. Each cultivar is having its specific genetic potential to produce exclusive yield attributing abilities and yield under favourable environmental condition.

In the present study, Laxmi recorded higher seed yield (2111.17 $\left.\mathrm{kg} \mathrm{ha}^{-1}\right)$ and stalk yield $\left(5639.67 \mathrm{~kg} \mathrm{ha}^{-1}\right)$ and harvest index $(27.23 \%)$ as compared to other two cultivars. The yield advantage of this cultivar over others might be attributed to the higher value of yield attributing characters such higher number of pods plant ${ }^{-1}$, more number of seeds pod ${ }^{-1}$, and maximum 100-seed weight etc. Different nutrient management practices had significant variation in the seed yield and stalk yield of pigeonpea. Among the treatments, application of $75 \%$ STBFR+ FYM $\left(5 \mathrm{t} \mathrm{ha}^{-1}\right)+$ lime $(0.2 \mathrm{LR})+$ sulphur $\left(20 \mathrm{~kg} \mathrm{ha}^{-1}\right)$ recorded significantly higher seed yield $(2061.33 \mathrm{~kg}$ ha $\left.{ }^{1}\right)$. This might be owing to FYM application in the soil which acted as slow-release source of nutrients, form different complexes with metal cation present in the soil and restricts their losses which leads steadily supply of nutrient in adequate amount and balanced proportion to the crop plants attributed to overall improvement in crop growth,yield attributes and finally the seed yield. This results were in accordance with findings of 
Pandey et al., (2015) and Goud and Kale (2010). Combined application of major nutrients with sulphur also resulted in higher yield of pigeonpea as per the findings of Deshbhratar et al., (2010).

\section{Nutrient uptake}

The nutrient uptake capacity of a plant depends upon the availability of nutrients and absorption capacity of plant which results in crop yield. Nutrient uptake is controlled by availability of both added and inherent sources of nutrients in the soil and absorption capacity, ramification and distribution of plant roots. The highest nitrogen uptake both in seed $\left(73.00 \mathrm{~kg} \mathrm{ha}^{-1}\right)$ and stalk $(104.03 \mathrm{~kg}$ $\mathrm{ha}^{-1}$ ) was found in cultivar Laxmi and the total nitrogen uptake (183.39 $\left.\mathrm{kg} \mathrm{ha}^{-1}\right)$ was found maximum by application of $75 \%$ STBFR+FYM $\left(5\right.$ tha $\left.^{-1}\right)+$ lime (0.2LR) + sulphur $\left(20 \mathrm{~kg} \mathrm{ha}^{-1}\right)$. The increasing $\mathrm{N}$ uptake might be due to increased availability of nitrogen to the crop, higher biomass production, more number of nodules plant ${ }^{-1}$, more yield and retarded the loss of chlorophyll and leaf nitrogen with increased photosynthesis.

The total phosphorus uptake (16.16 kg ha-1) was recorded highest values under application of $75 \%$ STBFR+ FYM $\left(5 \mathrm{t} \mathrm{ha}^{-1}\right)+$ lime $(0.2 \mathrm{LR})+\operatorname{sulphur}\left(20 \mathrm{~kg} \mathrm{ha}^{-1}\right)$ which was significantly different from other treatments. Similarly highest phosphorus uptake in seed and stalk was found in cultivar Laxmi. The increasing $\mathrm{P}$ uptake might be due to release of fixed phosphorus by the action of microorganisms present in rhizosphere. The total potassium uptake $\left(58.22 \mathrm{~kg} \mathrm{ha}^{-1}\right)$ was maximum under application of $75 \%$ STBFR+ FYM $\left(5 \mathrm{tha}^{-1}\right)+$ lime $(0.2 \mathrm{LR})+$ sulphur $(20$ $\mathrm{kg} \mathrm{ha}{ }^{-1}$ ) and cultivar Laxmi recorded the highest total potassium uptake $\left(57.47 \mathrm{~kg} \mathrm{ha}^{-1}\right)$ might be due to ability of tap root of pigeonpea to absorb potassium from deeper layer of soil. Similarly, the total sulphur uptake (4.79 $\mathrm{kg} \mathrm{ha}^{-1}$ ) was found maximum under application of $75 \%$ STBFR+ FYM $(5 \mathrm{t}$ $\left.\mathrm{ha}^{-1}\right)+$ lime $(0.2 \mathrm{LR})+\operatorname{sulphur}\left(20 \mathrm{kgha}^{-1}\right)$ and cultivar Laxmi recorded the highest sulphur uptake(4.53 $\left.\mathrm{kg} \mathrm{ha}^{-1}\right)$.

Among the cultivars, Laxmi recorded significantly the highest total nutrient $(\mathrm{N}+\mathrm{P}+\mathrm{K}+\mathrm{S})$ uptake of $252.85 \mathrm{~kg} \mathrm{ha}{ }^{-1}$.The total nutrient uptake was found maximum $\left(262.55 \mathrm{~kg} \mathrm{ha}^{-1}\right)$ under application of $75 \%$ STBFR+ FYM $\left(5 \mathrm{tha}^{-1}\right)+$ lime $(0.2 \mathrm{LR})+$ sulphur $\left(20 \mathrm{~kg} \mathrm{ha}^{-1}\right)$. The increase in total nutrient uptake due to combined use of FYM and lime along with STBFR. Liming has strong ameliorating effect on soil and organic acids produced from decomposition of FYM might be responsible for quick release of nutrients from native pool, resulting greater availability of nutrients to the crops. These results corroborated with findings of Jat and Ahalawat(2010).

\section{Economics}

The economics of production is the most important aspect of a study since no farmer will follow a practice that is not remunerative to him even if the yield and gross return becomes high and soil fertility is maintained. The maximum cost of cultivationfoundunderapplicationof $75 \% \mathrm{STBF}$ $\mathrm{R}+\mathrm{FYM}\left(5 \mathrm{tha}^{-1}\right)+$ lime $(0.2 \mathrm{LR})+$ sulphur $(20$ $\mathrm{kg} \mathrm{ha}^{-1}$ ) was due to combined use of FYM, lime and nutrients and more human labour as compared to other. The highest net return $\left(73,856 \mathrm{Rs}^{-h^{-1}}{ }^{-1}\right.$ and $\mathrm{B}: \mathrm{C}$ ratio (2.55) were recorded at nutrient level of $75 \%$ STBFR+ FYM (5t ha-1) + lime(0.2LR) + sulphur (20kg $\left.\mathrm{ha}^{-1}\right)$. The cultivar Laxmi, with the application of $75 \%$ STBFR+ FYM $\left(5 \mathrm{tha}^{-1}\right)+$ lime $(0.2 \mathrm{LR})+$ sulphur $\left(20 \mathrm{~kg} \mathrm{ha}^{-1}\right)$ resulted in the maximum net return (Rs. 80,680 ha $^{-1}$ ) and $\mathrm{B}: \mathrm{C}$ ratio $(2.84)$. 
Table.1 Effect of nutrient management practices on yield attributes and yield of pigeonpea cultivars during rabi season

\begin{tabular}{|c|c|c|c|c|c|c|c|}
\hline Treatments & $\begin{array}{l}\text { Pods plant }^{-1} \\
\text { (no.) }\end{array}$ & $\begin{array}{c}\text { Seeds } \\
\operatorname{pod}^{-1}(\text { no. })\end{array}$ & $\begin{array}{l}\text { Pod length } \\
\text { (cm) }\end{array}$ & $\begin{array}{c}\text { Seed } \\
\text { Index(g) }\end{array}$ & $\begin{array}{l}\text { Seed yield } \\
\left(\mathrm{kg} \mathrm{ha}^{-1}\right)\end{array}$ & $\begin{array}{l}\text { Stalk yield } \\
\left(\mathrm{kg} \mathrm{ha}^{-1}\right)\end{array}$ & $\begin{array}{c}\text { Harvest index } \\
(\%)\end{array}$ \\
\hline \multicolumn{8}{|l|}{ Cultivars } \\
\hline $\begin{array}{l}V_{1} \text { - BRG- } \\
4\end{array}$ & 38.88 & 3.62 & 4.70 & 11.46 & 1712.25 & 4860.33 & 26.25 \\
\hline$V_{2}-B R G-5$ & 36.63 & 3.46 & 4.63 & 12.75 & 1651.00 & 4860.08 & 25.26 \\
\hline $\begin{array}{r}V_{3}-\text { Laxmi } \\
(\text { ICPL-85063) }\end{array}$ & 43.90 & 4.03 & 5.14 & 12.11 & 2111.17 & 5639.67 & 27.23 \\
\hline $\operatorname{SEm}( \pm)$ & 1.29 & 0.06 & 0.08 & 0.21 & 26.05 & 99.99 & 0.48 \\
\hline $\begin{array}{l}\text { CD } \\
(\mathbf{P}=\mathbf{0 . 0 5})\end{array}$ & 3.77 & 0.17 & 0.24 & 0.61 & 76.40 & 293.26 & 1.39 \\
\hline \multicolumn{8}{|c|}{ Nutrient management practices } \\
\hline $\begin{array}{l}\text { F }_{1}- \\
\text { STBFR }\end{array}$ & 37.60 & 3.50 & 4.51 & 11.64 & 1510.00 & 4433.11 & 25.34 \\
\hline $\begin{array}{l}F_{2}- \\
75 \% \text { STBFR+F } \\
\text { YM }\left(5 \text { tha }^{-1}\right)\end{array}$ & 37.84 & 3.71 & 4.78 & 11.94 & 1787.22 & 4943.11 & 26.69 \\
\hline $\begin{array}{l}F_{3}-F_{2}+ \\
\text { Lime }(0.2 \text { LR })\end{array}$ & 39.18 & 3.76 & 4.89 & 12.20 & 1940.67 & 5340.56 & 26.23 \\
\hline $\begin{array}{l}F_{4}-F_{3}+ \\
\text { Sulphur } \\
\left(20 \mathrm{~kg} \mathrm{ha}^{-1}\right)\end{array}$ & 44.58 & 3.84 & 5.10 & 12.65 & 2061.33 & 5763.33 & 26.35 \\
\hline $\operatorname{SEm}( \pm)$ & 1.49 & 0.07 & 0.09 & 0.24 & 30.09 & 115.47 & 0.55 \\
\hline $\begin{array}{l}\text { CD } \\
(P=0.05)\end{array}$ & 4.36 & 0.20 & 0.27 & 0.70 & 88.22 & 338.62 & NS \\
\hline
\end{tabular}


Table 2: Effect of nutrient management practices on total $\mathrm{N}$ uptake, total $\mathrm{P}$ uptake,total $\mathrm{K}$ uptake, total S uptake andeconomics ofpigeonpea cultivars

\begin{tabular}{|c|c|c|c|c|c|c|c|}
\hline Treatments & $\begin{array}{c}\text { Total N } \\
\text { uptake } \\
\left(\mathrm{kg} \mathrm{ha}^{-1}\right)\end{array}$ & $\begin{array}{l}\text { Total P } \\
\text { uptake } \\
\left(\text { kg ha }^{-1}\right)\end{array}$ & $\begin{array}{c}\text { Total K } \\
\text { uptake } \\
\left(\text { kg ha }^{-1}\right)\end{array}$ & $\begin{array}{c}\text { Total S } \\
\text { uptake } \\
\left(\mathrm{kg} \mathrm{ha}^{-1}\right)\end{array}$ & $\begin{array}{c}\text { Total uptake } \\
(\mathrm{N}+\mathrm{P}+\mathrm{K}+\mathrm{S}) \\
\left(\mathrm{kg} \mathrm{ha}^{-1}\right)\end{array}$ & $\begin{array}{l}\text { Net return } \\
\left(\text { Rs. } \text { ha }^{-1}\right)\end{array}$ & $\begin{array}{l}\text { Benefit } \\
\text { Cost } \\
\quad \text { Ratio } \\
\end{array}$ \\
\hline \multicolumn{8}{|l|}{ Cultivars } \\
\hline $\begin{array}{c}\mathrm{V}_{1} \text { - BRG- } \\
4\end{array}$ & 140.63 & 10.78 & 44.23 & 3.05 & 198.68 & 57,413 & 2.32 \\
\hline $\begin{array}{l}\mathrm{V}_{2} \text { - BRG- } \\
5\end{array}$ & 136.97 & 9.65 & 42.23 & 3.35 & 192.19 & 53,788 & 2.23 \\
\hline $\begin{array}{r}V_{3}-\text { Laxmi } \\
(I C P L-85063)\end{array}$ & 177.03 & 13.82 & 57.47 & 4.53 & 252.85 & 80,680 & 2.84 \\
\hline SEm $( \pm)$ & 2.73 & 0.55 & 0.76 & 0.09 & 3.62 & - & 0.06 \\
\hline $\begin{array}{c}\mathbf{C D} \\
(\mathbf{P}=0.05)\end{array}$ & 8.03 & 1.61 & 2.25 & 0.28 & 10.62 & - & 0.18 \\
\hline \multicolumn{8}{|c|}{ Nutrient management practices } \\
\hline $\begin{array}{c}\text { F }_{1}^{-} \\
\text {STBFR }\end{array}$ & 117.79 & 6.98 & 36.93 & 2.60 & 164.30 & 54,263 & 2.54 \\
\hline $\begin{array}{l}\mathrm{F}_{2}- \\
75 \% \mathrm{STBFR}+\mathrm{F} \\
\text { YM }\left(5 \text { tha }^{-1}\right)\end{array}$ & 142.99 & 9.83 & 45.36 & 3.22 & 201.40 & 60,391 & 2.34 \\
\hline $\begin{array}{c}F_{3}-F_{2}+ \\
\text { Lime }(0.2 \text { LR })\end{array}$ & 162.01 & 12.68 & 51.39 & 3.97 & 230.05 & 67,330 & 2.43 \\
\hline $\begin{array}{c}\mathrm{F}_{4}-\mathrm{F}_{3}+ \\
\text { Sulphur } \\
\left(20 \mathrm{~kg} \mathrm{ha}^{-1}\right)\end{array}$ & 183.39 & 16.16 & 58.22 & 4.79 & 262.55 & 73,856 & 2.55 \\
\hline $\operatorname{SEm}( \pm)$ & 3.16 & 0.63 & 0.88 & 0.11 & 4.18 & - & 0.07 \\
\hline $\begin{array}{c}\text { CD } \\
(P=0.05)\end{array}$ & 9.27 & 1.86 & 2.60 & 0.32 & 12.27 & - & 0.21 \\
\hline
\end{tabular}


This might be due to the higher values of yield attributing characters that ultimately resulted in increase in yield with higher gross and net return. This is in confirmity with findings of Umesh et al., (2015) that application of higher level of nutrients recorded higher net return and benefit cost ratio owing to more seed yield in pigeonpea as compared to increase in cost of cultivation. The results revealed that application of $75 \%$ STBFR+ FYM $\left(5 \mathrm{t} \mathrm{ha}{ }^{-1}\right)+$ lime $(0.2 \mathrm{LR})+$ sulphur $\left(20 \mathrm{~kg} \mathrm{ha}^{-1}\right)$ to cultivar Laxmi was found beneficial by producing higher seed yield, gross return, net return and benefit cost ratio and showed significant effect on yield attributes and yield of pigeonpea.

\section{References}

Burns, R.C., and Hardy, RWF.1975. Nitrogen fixation in bacteria and higher plants, In molecular biology, biochemistry and biophysics, volume.21, Springer-verlag, Berlin, Germany.

Deshbhratar, P.B., Singh, P.K., Jambhulkar, A.P. and Ramteke, D.S. 2010. Effect of sulphur and phosphorus on yield, quality and nutrient status of pigeonpea (Cajanus cajan), Journal of Environmental Biology, 31(6): 933-937.

Gomez, K.A. and Gomez, A.A.1984. Statistical procedures for Agricultural Research, Second Edition, John Wiley and Sons, New York.

Goud, V.V. and Kale, H.B. 2010. Productivity and profitability of pigeonpea under different sources of nutrients in rainfed condition of central india, Journal of
Food Legumes, 23 (3\&4): 212-217.

Jat, R.A. and Ahlawat, IPS. 2010. Effect of organic manure and sulphur fertilisation in pigeonpea (Cajanus cajan L.) + groundnut (Arachis hypogaea L.) intercropping system, Indian Journal of Agronomy, 55(4): 276-281.

Kannaiyan, S. 1999. Bioreserved technology for sustainable agriculture, Associated Publishing Company. New Delhi. P- 422.

Pandey, I.B., Pandey, R.K. and Kumar, R. 2015. Integrated nutrient management for enhancing productivity and profitability of long duration pigeonpea (Cajanus cajan) under rainfed condition, Indian Journal of Agronomy, 60 (3): 436-442.

Panda, P.K., Mohapatra, P.M., Panigrahi, R.K., Kar, A., Mishra, IOP. and Bal, S.S. 2018. Performance of pigeonpea varieties at different dates of sowing during pre- rabi season, Indian Agriculturist, 62 (192): 41-46.

Reddy, K., Reddy, P.M., Kumari, P.L. and Krishna, T.G. 2015. Response of pigeonpea varieties to time of sowing during rabi season. Journal of Agriculture and Veterinary Sciences, 8 (2): 12-15.

Umesh, M.R., Shankar, M.A. and Ananda, N. 2015. Yield, nutrient uptake and economics of pigeonpea (Cajanus cajan L.) genotype under nutrient supply levels in dryland alfisols of Karnataka, Indian Journal of Agronomy, 58 (4): 554559.

\section{How to cite this article:}

Sunil Kumar Samantaray, Manoranjansatapathy and Satyananda Jena. 2020. Effect of Nutrient Management Practices on Yield Attributes, Yield, Nutrient uptake and Economics of Pigeonpea (Cajanus cajan L.) Cultivars during Rabi Season. Int.J.Curr.Microbiol.App.Sci. 9(03): 1709-1715. doi: https://doi.org/10.20546/ijcmas.2020.903.199 